\title{
Prospects for developing the legal regulation of digital platforms
}

\section{Perspectivas de desarrollo de la regulación legal de las plataformas digitales}

\author{
DOI: https://doi.org/10.17981/juridcuc.18.1.2022.02
}

Fecha de Recepción: 2021/04/08 Fecha de Aceptación: 2021/07/16

Elena Anatolyevna Kirillova $\odot$

Southwest State University. Kursk (Russian Federation)

South-Ural State University. Chelyabinsk (Russian Federation) elena.an.kirillova@mail.ru

Teymur El'darovich Zulfugarzade

Plekhanov Russian University of Economics. Moscow (Russian Federation) teymur.zulfugarzade@yandex.ru

\section{Oleg Evgenyevich Blinkov}

Academy of the FPS of Russia. Ryazan (Russian Federation)

State University of Humanities and Social Studies. Kolomna (Russian Federation) oleg.evg.blinkov@yandex.ru

\section{Olga Aleksandrovna Serova}

Pskov State University. Pskov (Russian Federation) olga.al.serova@yandex.ru

\section{Irina Aleksandrovna Mikhaylova}

Russian State Academy of Intellectual Property. Moscow (Russian Federation) irina.al.mikhaylova@yandex.ru

Para citar este artículo:

Kirillova, E., Zulfugarzade, T., Blinkov, O., Serova, O. \& Mikhaylova, I. (2022). Prospects for developing the legal regulation of digital platforms. Jurídicas CUC, 18(1), 35-52. DOI: http://dx.doi.org/10.17981/juridcuc.18.1.2022.02

\section{Resumen}

El estudio analizó las perspectivas para la regulación legal de las plataformas digitales estatales y privadas. Las plataformas digitales han sustituido el modelo de negocio lineal y han cambiado los principios económicos. La transición a la tecnología digital en la economía, los negocios y la esfera social, genera la necesidad de su regulación legal. El objetivo del estudio es examinar el estado legal de las plataformas digitales estatales y privadas, proponer un aparato conceptual, identificar las características clave de las plataformas digitales, y analizar las perspectivas para el desarrollo de la regulación legal en esta área. En el trabajo se utilizaron los métodos de análisis comparativo de los contextos de gestión en los sectores estatal y comercial, a través del método de generalización se propuso un criterio para la nueva tipificación de plataformas digitales, se utilizaron además, métodos de análisis, síntesis, deducción e inducción. El estudio propone una definición de autor de las plataformas digitales, una clasificación de las plataformas digitales, y concluye que la introducción de una nueva regulación especial de las plataformas digitales estatales y privadas, puede requerir la aprobación previa de esta regulación, por ejemplo, en el formato de un régimen legal experimental. Para la regulación integrada de las actividades de las plataformas digitales, es conveniente adoptar conceptos internacionales que permitan crear términos y principios uniformes. Al mismo tiempo, la regulación debe tener en cuenta las características de la regulación existente de ciertas áreas. En un caso, se basaría en un método dispositivo, en otro caso, en un método imperativo.

Palabras clave: Regulación legal; clasificación de plataformas digitales; plataformas digitales estatales; plataformas digitales privadas; enfoque de plataforma en la administración estatal

\section{Abstract}

The study considers the prospects for the legal regulation of public and private digital platforms. Digital platforms have replaced linear businesses and changed economic principles. The transition to digital technologies in the economy, business, and society substantiates the need for their legal regulation. The study aims at considering the legal status of public and private digital platforms, developing a new conceptual framework, determining the key features of digital platforms, and analyzing the prospects for developing legal regulation in this area. The paper compared management contexts in the public and commercial sectors. With the help of the generalization method, criteria for a new classification of digital platforms were proposed. The article used such methods as analysis, synthesis, deduction, and induction. The study represents a new definition of digital platforms, classifies them, and concludes that the introduction of special regulation of public and private digital platforms might require preliminary approbation, for example, in the form of an experimental legal regime. To ensure the comprehensive regulation of the activities of digital platforms, it is necessary to adopt international concepts that would allow creating uniform terms and principles. At the same time, regulation should consider the specifics of the existing regulation. On the one hand, it will be based on the dispositive method; on the other hand, it will be built over the imperative method.

Keywords: Legal regulation; classification of digital platforms; state digital platforms; private digital platforms; platform-based approach to public administration

(C) The author; licensee Universidad de la Costa - CUC 


\section{INTRODUCTION}

Digital platforms emerged in the 1990s due to the rapid development of information technology and the Internet. Platforms form the digital infrastructure of governments and markets by eliminating intermediaries, hierarchical links and promoting innovative business models (da Silva \& Chiarini, 2021).

The "platform" term was initially used in the IT-sphere but has also entered government practice and business models. The experience of developing certain state information systems created the necessary conditions for their transformation into digital platforms. Portals of public services, public procurement, and management personnel can be regarded as prototypes of digital platforms (Brown, Fishenden, Thompson \& Venters, 2017).

Public authorities have been using state information systems for many decades. In some cases, these information systems serve as the technological basis of digital state platforms. However, a state digital platform is a larger-scale tool than a state information system, both in terms of its functions and impacts on public, industrybased, and market processes. Therefore, the use of such platforms for public administration highlights the need to "platformize" public services and assess their potential social value.

The international system of public services has passed the stage of electronic government, at which the main functions of state information systems were reoriented to the electronic interaction with citizens and business entities. This stage implemented the declarative principle of obtaining public services through state portals and digital signatures, as well as entering data into state information systems (Stecken, Ebel, Bartelt, Poeppelbuss \& Kuhlenkötter, 2019). Currently, the digitalization of public services becomes even more intense: several life situations require public authorities to perform many public services simultaneously. This implies not only the combination of several state services belonging to different departments but also the provision of the related services with the involvement of third-party organizations as partners. Thus, 
both consumers and public service providers benefit in the process if we consider these subjects in a broad sense. A new phenomenon emerges, when an organization or citizen can be both a consumer of services and a supplier or partner of the state in the provision of such services (Kirillova, Okriashvili, Okriashvili, Yakupuv \& Pavlyuk, 2020). The interaction of the state with citizens and business entities on the Internet continues to transform and acquires the features typical of platforms.

Owners of private digital platforms gain much influence and control over supply chains. As a result, they can change prices and the balance between supply and demand by creating artificial information asymmetries. According to the Financial Times Global 500 , the five most valuable companies in the world are represented by such digital giants as Microsoft, Apple, Amazon, Alphabet, and Facebook. Each of them is connected with digital platforms and marketplaces (Jovanovic, Sjödin \& Parida, 2021). States face a previously unknown model of market control and cannot allow the digital monopolization of markets. At the same time, they are interested in using digital platforms for economic development and political expansion.

Many scholars analyzed public and private digital platforms in their scientific works. For example, Andersson (2017) considered the possibilities of digital platforms and their impact on the economy and law. Zutshi and Grilo (2019) traced the formation and development of digital platforms and their impact on industrial engineering. An interesting aspect was mentioned in the article written by Gawer (2020). She drew attention to the interaction of the company's field of activity, platform parties, and digital interfaces. Haberly, MacDonald-Korth, Urban and Wójcik (2019) studied the possibility of asset management using digital platforms. Habrat (2020) addressed the legal challenges of digitalization and the use of private digital platforms. Lathrop \& Ruma (2010) examine the legal aspect of state actions in the field of digital platforms. The phenomenon of digital platforms requires further scientific research since this concept has not been established and the mechanism for integrating platforms 
into the regulatory and organizational framework of public administration has to be developed. Most countries of the world still do not have the special regulation of public and private digital platforms, therefore it is necessary to consider the challenges related to the development of special regulation for digital platforms.

The phenomenon of digital platforms requires further scientific understanding, since the concept itself has not yet been established, and the mechanism for embedding platforms in the regulatory and organizational contexts of the public administration system has yet to be developed. As for the special regulation of public and private digital platforms, in most countries of the world, it is still absent. Therefore, it is necessary to consider the challenges facing the state in terms of developing special regulations for digital platforms.

The study aims at considering the legal status of public and private digital platforms, developing a new conceptual framework, determining the key features of digital platforms, and analyzing the prospects for developing legal regulation in this area.

\section{Methodology}

In the course of the study, we reviewed the corresponding scientific literature, analyzed the use of public and private digital platforms, and examined the existing classifications of various platforms. While comparing management contexts in the public and commercial sectors, we highlighted the differences between public and commercial digital platforms. To define a digital platform, we considered and systematized the existing classifications of platforms. Using the generalization method, we developed the following criteria for a new classification of digital platforms: the functions implemented, the economic model used, the technologies used, and the industry affiliation.

The evidential basis was formed by cases from the relevant academic and special literature, the practical application of various platforms, and expert consultations in the field of platform management. 
This article is conceptual. It aims at formulating a new subject area of digital public administration based on platforms, assuming its further research and practical implementation.

\section{RESULTS}

State digital platforms form and regulate industry-based processes, make relations between various departments transparent through secure participation technologies, assessments, and comprehensive mechanisms for creating value for each participant and the industry as a whole (Dijck, 2019). However, state digital platforms can be used not only within one industry but also for cross-industry interaction due to open architectural standards. They require greater coordination of public authorities, as well as the choice of an operator who will establish and harmonize relationships between various groups of platform participants. Considering public and private digital platforms, we can emphasize their common features, including the concentration of efforts around the key interaction and the focus on solving a specific problem at the first stage of creating a platform. Public and private digital platforms personalize the needs and demands of users, analyze and change the structure of data on the user behavior presented on a platform to better understand their needs and improve the services provided (Zutshi \& Grilo, 2019).

There are different definitions of digital platforms. For instance, the Digital Republic Act (France) defines a digital platform in the following manner:

Any natural or legal person that offers for business purposes, for free or in exchange for compensation, an online communication service to the public that is based on 1) ranking or listing using digital algorithms of content, goods or services offered or put online by third parties; or 2) establishing relationships between parties in view of the sale of goods, the offering of services or the exchange or sharing of content, goods or services (Marsden, Meyer \& Brown, 2020, p. 5). 
This definition is of scientific interest because a digital platform is identified with a person offering such services, the activities of such persons should be professional, and legal entities and individuals can act as operators.

There is also another definition of a digital platform as a disruptive innovation or an integrated information system that provides multilateral user interactions for the exchange of data and values, leading to a decrease in overall transaction costs, optimizing business processes, and increasing the efficient supply chain of goods and services (Habrat, 2020). The European Commission has defined a digital (online) platform as an enterprise operating in two-sided or multilateral markets that uses the Internet to provide interaction between two or more separate but interdependent groups of users (consumers). A study specifically commissioned by the European Parliament proposed a broader definition that a digital platform provides a (technological) basis for the provision or aggregation of services (content) from service providers (content) to end-users.

Since there is a wide variety of such definitions, many experts consider platforms as a digital form of organizing interaction between suppliers and consumers to minimize transaction costs when searching for partners, goods, services, organizing payments, concluding contracts, monitoring the execution of agreements, assessing the reputation of industry participants, etc. (Lathrop \& Ruma, 2010).

Platforms are created not only for business purposes but also for government needs, and can be defined in the following way: a digital platform is a system of mutually beneficial algorithmic relationships between a significant number of independent actors in the sphere of government activity or an economic branch, carried out in a unified information environment and leading to a decrease in transaction costs due to the use digital technologies for processing data and changing the division of labor.

Platforms should be distinguished from the larger, more complex, and dynamic information infrastructures that are built over platforms. A digital platform accelerates the exchange of value among two or more groups of users, consumers, and producers (Hasan \& 
Starly, 2020), controls and evaluates the result, and in case of a dispute between the supplier and the consumer can even act as the primary arbitrator. Platforms provide their users with a clear system of service monetization. To implement functions of a particular platform, a complex architecture of digital solutions is formed, which requires serious organizational and regulatory changes (Sullivan, 2018).

The most effective platforms use a positive network effect or a simultaneous increase in suppliers and consumers of goods and services. The more participants are involved in such interaction (i.e. the higher is the positive network effect), the more benefits all the participants in the platform interaction get and the lower are their interaction costs (Moazed \& Johnson, 2016).

Digital platforms can be classified based on four criteria:

Functions, economic models, technologies, and industries (Fig. 1).

\begin{tabular}{l} 
According to functions \\
- Advertising Platforms (Google, Facebook, etc.) \\
- Cloud Platforms (AWs, Salesforce, etc.) - lease equipment to companies \\
- Industrial Platforms (General Electric, Siemens, etc.) - develop equipment and software for \\
companies \\
- Product Platforms (Rolls Roys, Spotify, etc.) - provide a subscription to their product \\
- Lean Platforms (Uber, Airbnb, etc.) \\
\hline According to economic models \\
- Aggregators whose algorithms form the price of the platform product (Yandex. Taxi, etc.) \\
- Aggregators that work with the market price of the platform product (Yandex Market, Amazon, \\
etc.) \\
\hline According to technologies \\
- Platforms offering commoditized services that involve the automatic selection of suitable \\
options (Uber, Yandex.Taxi, etc.) \\
- Platforms offering non-commercialized services that do not automatically search for suitable \\
options (Airbnb, Booking.com) \\
\hline According to industries \\
- Services for corporations and organizations \\
- Job search service, platforms and supply chain management \\
- Food: food delivery, food sharing and food preparation \\
- Goods: rental goods, manufacturing support and the purchase of used items \\
- Health: mutual assistance and medical services \\
- Fducation: honk sharing, instructor-led nnline training and mutual exchange \\
- Logistics: local delivery, shipment and storage \\
- Mobility services: vehicle call, assistance and support, parking services \\
- Munial services: crowdfunding, cryptocurrencies, loans services, etc. \\
\hline
\end{tabular}

Fig. 1. The classification of digital platforms. Source: Authors. 
The above-mentioned systematization of various classifications proves that there is practically no platform that can be characterized solely by one criterion. Each platform is a complex phenomenon that combines technological, organizational, industry-based, and many other aspects that affect the interaction of participants and the distribution of value. Platforms that are in constant development can acquire new features over time, capture new markets and increase the range of their functions (Gil-Garcia, 2012).

This can cause problems. In 2019, Bayer and Monsanto announced their merger. Both companies occupy an independent position in the digital field of breeding and agrochemistry. Due to this merger, the largest entity could appear on the product market, which would establish significant barriers for other companies that plan to enter the relevant market (Haenschen \& Wolf, 2019). When these companies or other organizations merge, there can be the following risks (Fig. 2).

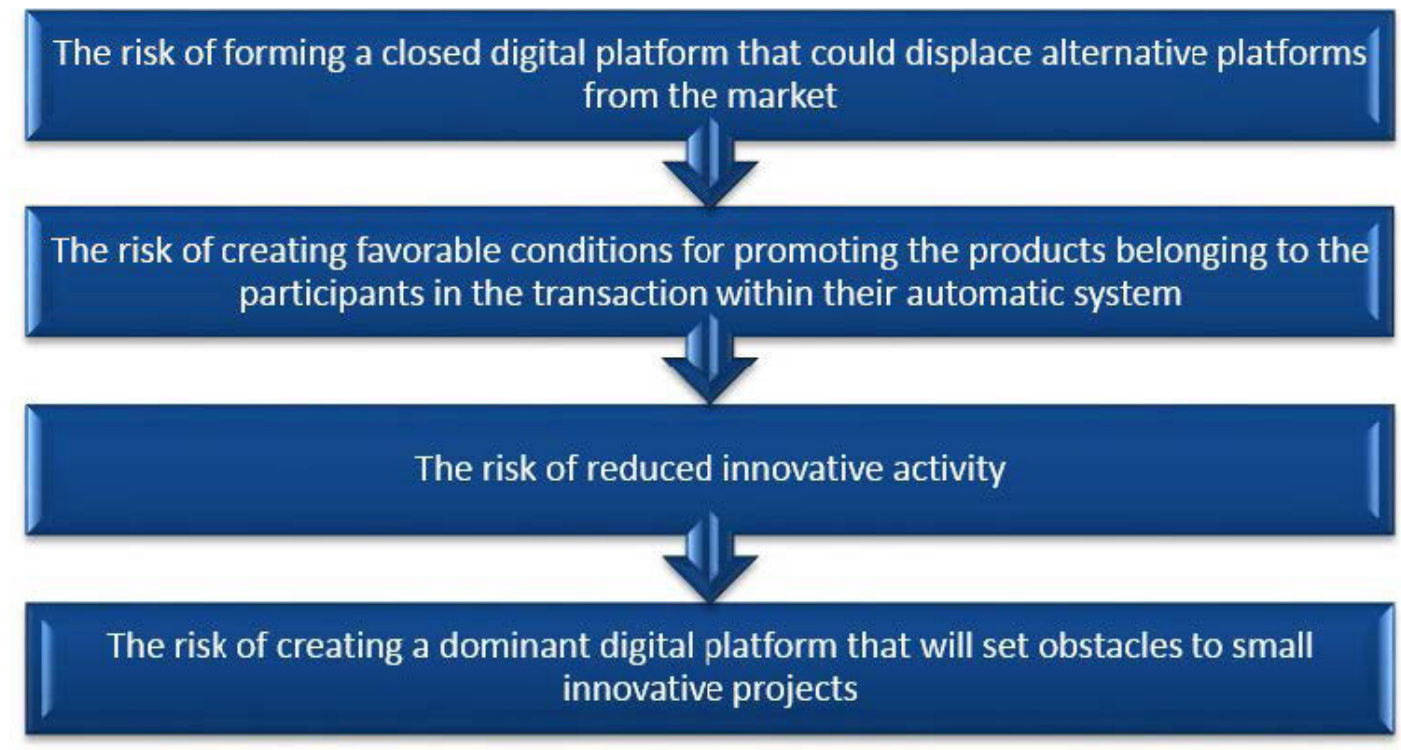

Fig. 2. The risks of merging digital platforms.

Source: Authors.

The assessment of any transaction should be based not only on the consideration of the company's shares but also on the analysis of possible consequences for competition. As a result, a merger should 
meet the following requirements: companies should implement technology transfer and provide other companies with access to the key information. Most often, projects related to the operation of digital platforms are associated with the risks of antitrust regulation (Andersson, 2017). In this regard, the US and EU regulation was supplemented with new criteria for assessing economic concentration, namely, considering its influence on innovations. This criterion is calculated by assessing possible consequences for the innovation activity of companies, competitors, and the market as a whole. For example, the merger of competitors causes a decrease in the research and innovation activities of such companies (Janssen \& Estevez, 2013). On the contrary, the merger of similar companies can result in the creation of a new IT solution or a research project, which contributes to the development of innovations.

\section{Discussion}

The Organization for Economic Co-operation and Development (OECD) notes the active development of multi-sided online platforms that create platforms for trade in goods, provision of services, and exchange of information in both physical and digital form. In recent years, many Internet companies (Apple, Google-Alphabet, Amazon, Alibaba, Facebook, Uber, Netflix, etc.) have begun to act as digital online platforms that trade and provide services on electronic platforms (marketplace) or payment. Settlement operations are either focused on meeting the needs for the search and processing of information within the framework of search services or social networks. Digital business is supported by a variety of technology platforms, which include various combinations of individual digital technology platforms (portals), and in particular: an office organization and support platform and API management programs; customer portal and supplier portal for electronic transactions; business intelligence and master data monitoring; end devices and security and management tools within the Internet of Things (IoT); operational technological systems that directly control equipment (in the industry, these are industrial control systems or dispatch control, 
SCADA) or energy management systems, substation automation; in the healthcare system, these are clinical systems and technologies; in communication systems - executive systems, telematic and telecommunication network equipment fleet and operational digital technologies), etc.

There is a wide variety of online platforms (digital technology platforms) that cover a wide range of activities, including online advertising platforms, shopping platforms, search engines, social media and creative content channels, application distribution platforms, communication services, payment systems, and collaborative business platforms. The digital economy is based on online platforms where customers can buy goods or order services (Airbnb, Uber, Amazon). The current legislation of European countries usually regulates the bilateral relationship between the consumer and supplier. On the other hand, platforms are often tripartite business models that require the lender and supplier not only to enter into an agreement with each other but also to enter into an agreement with the platform operator. The construction of contractual relations with the participation of digital platforms can be carried out based on various models of contractual relations, namely based on commission agreements, or a service agreement for the transfer of goods and selection of a manufacturer, or a mixed model combining several contracts with different subjects: suppliers of goods of work, services and aggregator, as well as recipients (consumers) of goods, works, and services and aggregators. Some researchers believe that a special model of contractual relations is also possible - the sui generis model, i.e. a special type of contractual relationship involving a digital platform (Ivanov, 2017). Now, in the process of digital transformations, new subjects of civil turnover are being formed - digital technological (online) platforms (digital corporations), the owners (operators) of which are subjects of various organizational and legal forms. As a result, the need for the special legal regulation of this sphere of civil relations is revealed. 
Characterizes platforms by the multi-sidedness of their business model and the existence of network effects across sides. Sides are defined as either "users" (as in the European Commission definition, above) or "customers" of the platform (Evans \& Schmalensee, 2016, p. 15); both users and customers can be individuals or business organizations (da Silva \& Chiarini, 2021). Platforms generate value by reducing transaction costs (Dijck, 2019) and by acting as "matchmakers" among economic agents, helping members of their various sides to "productively interact" (Gawer, 2020).

The differences between single-sided businesses and multi-sided platforms are stark. Ordinary businesses buy inputs of various sorts from suppliers, sometimes transform them into finished products, and sell goods or services to customers. Their main focus is on attracting customers and selling to them on profitable terms. Multi-sided platforms, in contrast, need to attract two or more types of customers by enabling them to interact with each other on attractive terms. Their most important inputs are generally their customers (Evans \& Schmalensee, 2017, p. 15).

The state acceptance of sharing platforms, together with the introduction of the legal framing for them, particularly gains strength from the frame promising digital future. In such policy-framing processes, sharing platforms' extra-legal entry into the market as a form of "elite informality" becomes accepted instead of being considered illegal (Lanamäki \& Tuvikene, 2021, p. 1).

The existing regulation of projects related to digital platforms demonstrates that there are areas that cannot be controlled by the current laws. Within the context of public administration, the introduction of platforms has not only technological features but also certain organizational and regulatory aspects (Perry, 2016). The legal regulation of digital platforms is controversial. Some experts suggest using an imperative approach to the legal regulation of digital objects and the digital environment. To apply this approach, it is necessary to develop a special law that will consider the specific creation and operation of public and private digital platforms, while legislation will regulate all the risks in 
accordance with legal possibilities (Haberly et al., 2019). However, there are also disadvantages of the imperative regulation of legal relations in the field of digital platforms. The digital economy goes through constant and rapid changes, therefore it can be impossible to regulate all the emerging issues since the adoption of new laws or amendments takes time. No one can predict the development of digital platforms and their functions, which makes it hard to ensure timely and effective legal regulation in this area. If the legal regulation of digital platforms is based on general provisions of the current norms, situations might arise when the legislation does not consider the specific use of public and private digital platforms (Gawer, 2020).

When using a dispositive approach to the legal regulation of public and private digital platforms, strategic documents, concepts, and guidelines can be created. The current norms can be specified to adapt to the legal regulation of specific objects of law, including digital platforms. The dispositive approach will enable self-regulation and contractual regulation, as well as provide an opportunity to conclude agreements between the regulator and the regulated ones (for example, the inclusion of regulatory norms as an annex to the concession or investment agreement). It will be possible to create associations and self-regulatory organizations in which the regulator controls the existence of rules, procedures, and measures for their implementation. In this case, the regulation of legal relations will be carried out by the market participants.

In relation to the legal regulation of digital platforms, experimental legal regimes can be used, for example, legal regimes associated with the development and implementation of artificial intelligence technologies upon the constant monitoring of the regulator (Mäntymäki, Baiyere \& Islam, 2019). Experimental legal regimes can be formed for temporary regulation, but if they prove to be an effective means of regulation, then it can be discussed whether to establish permanent legal acts or amend the existing legislation.

Today, the main approaches to the regulation of public and private digital platforms are to establish special rules or amend the current 
legislation that considers the specifics of digital platforms. In France, the Tax Code was amended and supplemented with the rules that set several obligations of the enterprise as a platform operator (the operator is obliged, with each transaction, to provide accurate, clear, and transparent information about the tax and social obligations of the persons who carry out the transaction through the platform) (Delgosha \& Hajiheydari, 2020).

To ensure the legal regulation of public and private platforms, it is necessary to consider the principles on which regulation is based. These principles are specific and can be used in the regulation of legal relations related to digital products and the digital environment (Fig. 3).

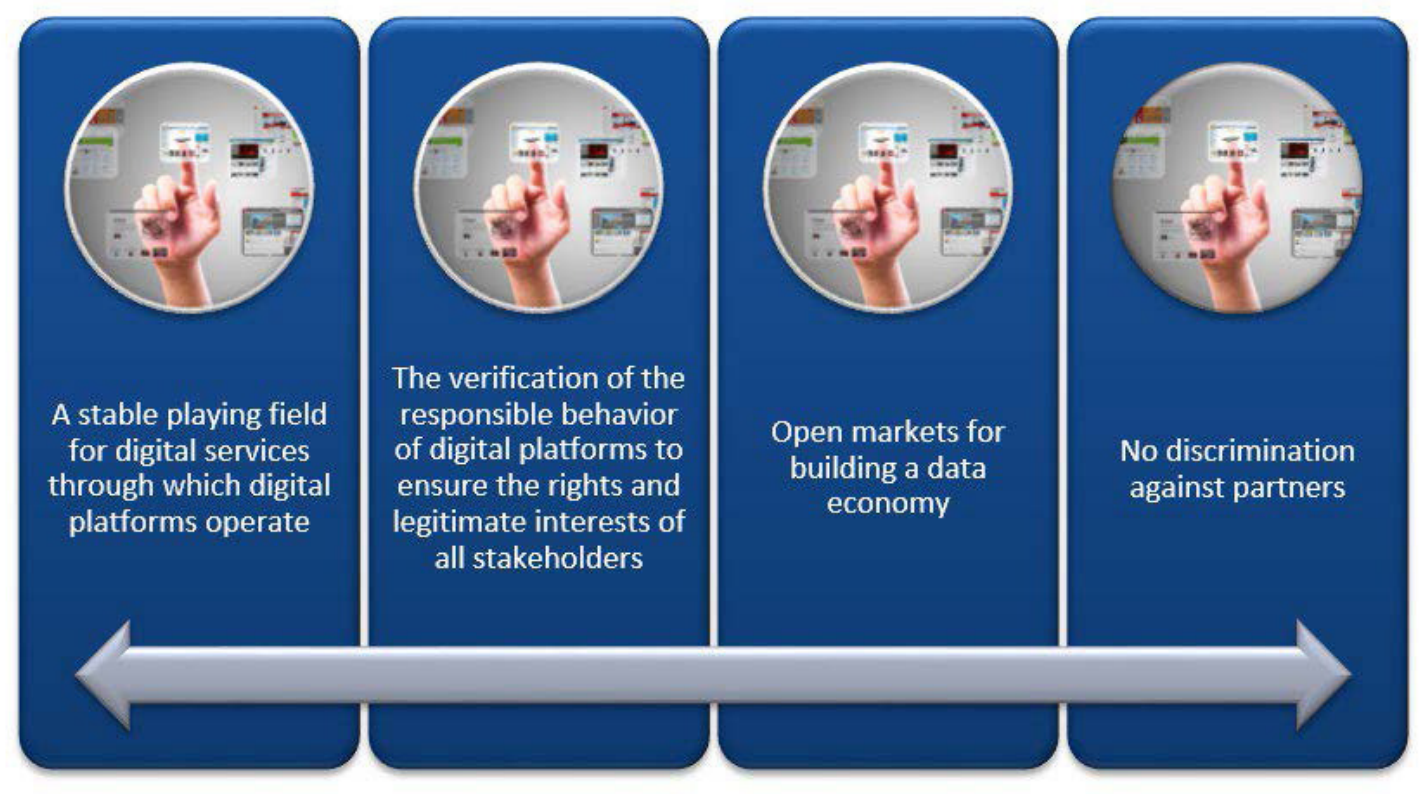

Fig. 3. Principles of the legal regulation of public and private platforms. Source: Authors.

The legal regulation of digital platforms can comprise various legislative acts. Thus, it is advisable to use provisions on the prohibition of abuse of one's dominant position, the prohibition of unfair competition, and the implementation of state control over economic concentration from the antimonopoly legislation. It is also necessary to borrow requirements for the disclosure of information 
related to the activities of an organization and the confidentiality of information, including personal data, from the information legislation (Klievink, Bharosa \& Tan, 2016). Legal relations with digital platforms utilize contractual mechanisms. These are the establishment of requirements for the terms of accession agreements and the enforcement of obligations, including insurance and bank guarantees, and other contractual mechanisms. The priority direction for the development of digital platforms will be the creation of a preferential tax regime, subsidies, and the provision of preferences (Bozeman, 2002).

\section{Conclusions}

A digital platform is a system of mutually beneficial algorithmic relationships between a significant number of independent actors in the sphere of government activity or an economic branch, carried out in a unified information environment and leading to a decrease in transaction costs due to the use of digital technologies for processing data and changing the division of labor.

The regulation of digital platforms is a difficult task since the state needs to find a balance between respecting the interests of third parties and applying permissive rules.

In modern conditions, an integrated and ecosystem-based approach to legal regulation becomes especially important, when the necessary changes are considered immediately in relation to all the elements of public and private digital platforms. The introduction of new special regulation of public and private digital platforms might require preliminary approbation, for example, in the form of an experimental legal regime. To ensure the comprehensive regulation of digital platforms and their activities, it is recommended to adopt international concepts. This would allow creating uniform terms and principles, while regulation should consider the specifics of the existing regulation: on the one hand, it will be based on the dispositive method, on the other hand, it will be built over the imperative method. 
In the subsequent studies, it is necessary to consider the specific legal status of public and private digital platforms, the methods of legal regulation used in different countries, and their effectiveness.

\section{REFERENCES}

Andersson, J. (2017). Platform logic: an interdisciplinary approach to the platform-based economy. Policy \& Internet, 9(4), 374-394. https://doi.org/10.1002/poi3.159

Bozeman, B. (2002). Public-value failure: when efficient markets may not do. Public Adminis-tration Review, 62(2), 145161. Dsiponible en https://www.jstor.org/stable/3109898

Brown, A., Fishenden, J., Thompson, M. \& Venters, W. (2017). Appraising the impact and role of plat-form models and Government as a Platform (GaaP) in UK Government public service re-form: towards a Platform Assessment Framework (PAF). Government Information Quarterly, 34(2), 167-182. https://doi.org/10.1016/j.giq.2017.03.003

da Silva, V. J. \& Chiarini, T. (2021). Technological progress and political systems: non-institutional digital platforms and political transformation. Technology in Society, 64(C), 101460. https://doi.org/10.1016/j.techsoc.2020.101460

Delgosha, M. S. \& Hajiheydari, N. (2020). On-demand service platforms pro/anti adoption cognition: Examining the contextspecific reasons. Journal of Business Research, 121, 180194. https://doi.org/10.1016/j.jbusres.2020.08.031

Dijck, J. (2019). Governing digital societies: private platforms, public values. Computer Law \& Security Review, 36, 1-4. https://doi.org/10.1016/j.clsr.2019.105377

Evans, D. S. \& Schmalensee, R. (2017). Multi-sided Platforms. In: M. Vernengo, E. Pérez \& B. Rosser (ed.), The New Palgrave Dictionary of Economics. London: Palgrave Macmillan. https://doi.org/10.1057/978-1-349-95121-5_3069-1 
Gawer, A. (2020). Digital platforms' boundaries: the interplay of firm scope, platform sides, and digital interfaces. Long Range Planning, [In Press], 1-16. https://doi.org/10.1016/j. lrp.2020.102045

Gil-Garcia, R. (2012). Towards a smart state? Inter-agency collaboration, information integration and beyond. Information Polity, 17(3-4), 269-280. https://doi.org/10.3233/IP-2012000287

Haberly, D., MacDonald-Korth, D., Urban, M. \& Wójcik, D. (2019). Asset management as a digital platform industry: a global financial network perspective. Geoforum, 106, 167-181. https://doi.org/10.1016/j.geoforum.2019.08.009

Habrat, D. (2020). Legal challenges of digitalization and automation in the context of Industry 4.0. Procedia Manufacturing, 51, 938-942. https://doi.org/10.1016/j.promfg.2020.10.132

Haenschen, K. \& Wolf, J. (2019). Disclaiming responsibility: how platforms deadlocked the Federal Election Commission's efforts to regulate digital political advertising. Telecommunications Policy, 43(8), 101824. https://doi.org/10.1016/j. telpol.2019.04.008

Hasan, M. \& Starly, B. (2020). Decentralized cloud manufacturingas-a-service (CMaaS) platform architecture with configurable digital assets. Journal of Manufacturing Systems, 56(2), 157-174. https://doi.org/10.1016/j.jmsy.2020.05.017

Ivanov, A. A. (2017). Aggregation business and law. Law, 5, 145-156. Janssen, M. \& Estevez, E. (2013). Lean government and platformbased governance - doing more with less. Government Information Quarterly, 30(1), 1-8. https://doi.org/10.1016/j. giq.2012.11.003

Jovanovic, M., Sjödin, D. \& Parida, V. (2021). Co-evolution of platform architecture, platform services, and platform governance: expanding the platform value of industrial digital platforms. Technovation, [In Press]. https://doi.org/10.1016/j. technovation.2020.102218 
Kirillova, E. A., Okriashvili, T. G., Yakupuv, A. G. \& Pavlyuk, A. V. (2020). Legal status, role and features of electronic document management. Utopia y Praxis Latinoamericana, 25(Extra12), 178-186. https://doi.org/10.5281/zenodo.4280116

Klievink, B., Bharosa, N. \& Tan, Y.-H.. (2016). The collaborative realization of public values and business goals: Governance and infrastructure of public-private information platforms. Government Information Quarterly, 33(1), 67-79. https:// doi.org/10.1016/j.giq.2015.12.002

Lanamäki, A. \& Tuvikene, T. (2021). Framing digital future: selective formalization and legitimation of ridehailing platforms in Estonia. Geoforum, [In Press]. https://doi.org/10.1016/j. geoforum.2021.01.016

Lathrop, D. \& Ruma, L. (2010). Government as a platform. In: D. Lapthrop \& L. Ruma, Open Government, (pp. 13-40). Sebastopol: O'Reilly.

Marsden, C., Meyer, T. \& Brown, I. (2020). Platform values and democratic elections: how can the law regulate digital disinformation? Computer Law \& Security Review, 36(1), 105373. https://doi.org/10.1016/j.clsr.2019.105373

Mäntymäki, M., Baiyere, A. \& Islam, A. (2019). Digital platforms and the changing nature of physical work: Insights from ridehailing. International Journal of Information Management, 49, 452-460. https://doi.org/10.1016/j.ijinfomgt.2019.08.007

Moazed, A. \& Johnson, N. L. (2016). Modern monopolies: what it takes to dominate the 21st century economy. New York: Saint Martins' Press.

Perry, M. J. (2016). The platform transformation: how IoT will change IT, and when. Sebastopol: O'Reily Media.

Stecken, J., Ebel, M., Bartelt, M., Poeppelbuss, J. \& Kuhlenkötter, B. (2019). Digital shadow platform as an innovative business model. Procedia CIRP, 83, 204-209. https://doi. org/10.1016/j.procir.2019.02.130 
Sullivan, C. (2018). Digital identity - from emergent legal concept to new reality. Computer Law \& Security Review, 34(4), 723-731. https://doi.org/10.1016/j.clsr.2018.05.015

Zutshi, A. \& Grilo, A. (2019). The Emergence of digital platforms: a conceptual platform architecture and impact on industrial engineering. Computers \& Industrial Engineering, 136, 546-555. https://doi.org/10.1016/j.cie.2019.07.027

Elena Anatolyevna Kirillova. Ph.D. in Law, Russian Federation Southwest State University, Kursk, Russian Federation, South-Ural State University (National Research University) (Chelyabinsk, Russian Federation). https://orcid.org/0000-0001-7137-901X

Teymur El'darovich Zulfugarzade. Ph.D. in Law, Department of Civil Legal Disciplines, Plekhanov Russian University of Economics (Moscow, Russian Federation). https://orcid.org/0000-00020778-1511

Oleg Evgenyevich Blinkov. Doctor of Law, Academy of the FPS of Russia, Ryazan, Russian Federation, State University of Humanities and Social Studies (Kolomna, Moscow region, Russian Federation). https://orcid.org/0000-0002-3506-2194

Olga Aleksandrovna Serova. Doctor of Law, Pskov State University (Pskov, Russian Federation). https://orcid.org/0000-0003-41137399

Irina Aleksandrovna Mikhaylova. Doctor of Law, Russian State Academy of Intellectual Property (Moscow, Russian Federation). https://orcid.org/0000-0001-7305-5668 